\title{
Role of livestock in sustainable agriculture for food security
}

\author{
Maria $V$. Karpova ${ }^{1, *}$, Nina $V$. Roznina ${ }^{1}$, Aliya $U$. Esembekova ${ }^{1}$, Alla $V$. Shulgina ${ }^{2}$, and \\ Valentina M. Flakina ${ }^{2}$ \\ ${ }^{1}$ Kurgan State Agricultural Academy by T.S. Maltsev, Kurgan, Russia \\ ${ }^{2}$ Kurgan State University, Sovetskaya Str., 63, 4, Kurgan, Russia
}

\begin{abstract}
The livestock sector plays a special role in the formation of the rural economy and the life of society, performing a wide range of different functions. Agriculture, as a result of its activities, provides new jobs, in connection with which unemployment is reduced, there is also a decrease in rural migration, there is a change in the competitive environment, as a result of which the needs of the food market are being satisfied. A comprehensive assessment of the impact of animal husbandry on the development of the territory of the Kurgan region is the goal of our study. The article examines the development trends of the industry on the example of the Kurgan region. The influence of the development of animal husbandry on the provision of food security in the region has been studied. Such indicators as the volume of agricultural products for all types of categories, livestock, production of basic livestock products by categories of farms in the Kurgan region for 2016-2020 were considered and analyzed.
\end{abstract}

\section{Introduction}

The livestock sector is a strategically important production activity that provides the necessary food resources in solving food security problems. Trends in livestock production have a significant impact on how well these problems are addressed. In modern conditions in animal husbandry, agricultural producers are an important element of the national agrifood system, making up a certain part of the production of all livestock products. Subjects of all categories of agriculture help in solving the problems of rural development of a social nature. Livestock farming is an integral part of the agri-food system of the Kurgan region, it affects the food and economic security of the country and its regions, preserves the quality of the environment, maintains landscapes, provides employment for the population, socioeconomic development of rural areas, and etc. Therefore, a comprehensive analysis and definition of the role of animal husbandry in the development of agriculture is relevant.

\footnotetext{
* Corresponding author: mdusheva@rambler.ru
} 


\section{Materials and methods}

The study used statistical data from the Federal State Statistics Service. All the main branches of animal husbandry are considered; the dynamics of the livestock population, the volume of agricultural production, and the production of basic livestock products by categories of farms were considered as indicators reflecting the development of livestock industries.

In the process of writing the paper, various methods of scientific study were used, such as observation and collection of facts, analysis and synthesis, graphic.

\section{Results and discussion}

Support for small businesses has proven its relevance and will continue in the Kurgan region. Unprecedented attention is paid to development of small businesses in the region. In total, in 2020, 38 grants were issued to novice farmers, 11 grants to family farms, 3 grants to agricultural consumer cooperatives, for the first time 33 regional grants were provided for formation and improvement of peasant (farm) farms. So that farms can successfully develop further, the Department of AIC is developing a mechanism that allows them to sell products, incl. enterprises that have taken advantage of state support [1-2].

In the region, as of January 1, 2021, the following were recorded: 1138 peasant (farming) households (according to statistics); 27 agricultural consumer cooperatives, of which 4 - credit, 13 - processing, 8 - supply and marketing, 2 - service; 167.8 thousand families with personal subsidiary plots [3-4].

The main task of animal husbandry is to meet the needs of the population for food resources. Agricultural production represents data on the volume of crop and livestock production of all agricultural producers, including private sector farms (household farms, peasant (farm) households and individual entrepreneurs), in a cost estimate at actual prices (Table 1).

Table 1. The volume of agricultural products by categories of farms, mln.r.

\begin{tabular}{|c|c|c|c|c|c|}
\hline & 2016 & 2017 & 2018 & 2019 & 2020 \\
\hline \multicolumn{6}{|c|}{ Farms of all categories } \\
\hline $\begin{array}{l}\text { Production volume } \\
\text { total }\end{array}$ & 38094.0 & 38576.7 & 39511.4 & 46268.9 & 42823.4 \\
\hline \multicolumn{6}{|l|}{ including: } \\
\hline crop industry & 21890.1 & 23452.7 & 22248.2 & 29732.6 & 26494.5 \\
\hline livestock industry & 16203.9 & 15124.0 & 17263.2 & 16536.3 & 16328.8 \\
\hline \multicolumn{6}{|c|}{ Households of the population } \\
\hline $\begin{array}{l}\text { Production volume } \\
\text { total }\end{array}$ & 16868.4 & 15777.2 & 17471.8 & 17615.2 & 15377.5 \\
\hline \multicolumn{6}{|l|}{ including: } \\
\hline crop industry & 4819.3 & 5356.7 & 5215.6 & 5928.1 & 4373.9 \\
\hline livestock industry & 12049.1 & 10420.5 & 12256.3 & 11687.1 & 11003.6 \\
\hline \multicolumn{6}{|c|}{ Peasant (farming) households and individual entrepreneurs } \\
\hline $\begin{array}{l}\text { Production volume } \\
\text { total }\end{array}$ & 6684.4 & 6921.1 & 6907.7 & 9614.6 & 9074.5 \\
\hline \multicolumn{6}{|l|}{ including: } \\
\hline crop industry & 6169.9 & 6356.5 & 6053.1 & 8759.3 & 8110.2 \\
\hline livestock industry & 514.5 & 564.6 & 854.6 & 855.3 & 964.3 \\
\hline
\end{tabular}

* according to the data of the Federal State Statistics Service 
The volume of production of individual agricultural entrepreneurs in 2020 and households of the total value of agricultural production in the region amounted to about $57 \%$ (Table 1, Figure 1), while the structure of production changes insignificantly over this period.

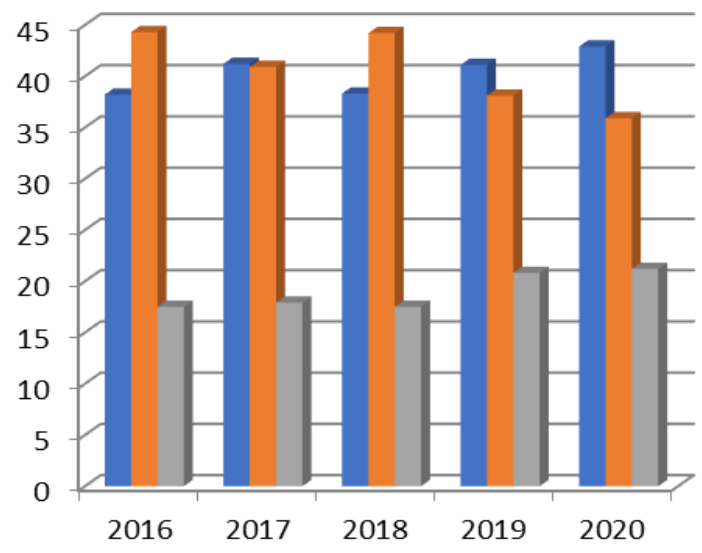

Agricultural organizations

- Households of the population

- Peasant (farming)

households and individual entrepreneurs

Fig. 1. Percentage of agricultural products by categories of farms, $\%$

The largest share of the volume of production, $44.3 \%$ in 2016, was obtained in household farms, the smallest share of $17.5 \%$ in peasant farms. During the period under review, this structure has changed and in 2020 the largest share of agricultural production was received in agricultural organizations and amounted to $42.9 \%$, the least $21.2 \%$ also in peasant farms. The volume of output for the analyzed period increased in agricultural organizations by $4.7 \%$, in peasant farms by $3.7 \%$, in households, this indicator decreased by $8.4 \%$, during this period a decline in production is observed in households, both for crop production and livestock production, which is associated with a decrease in acreage in households.

The composition of livestock products includes the cost of raw products obtained as a result of growing and economic use of farm animals and poultry (milk, wool, eggs, and etc.), the cost of growing (offspring, growth, weight gain) of livestock and poultry according to the data of the analyzed period, and etc. [5.6].

One of the main indicators reflecting the level and dynamics of the development of animal husbandry are indicators of the number and composition of the livestock of farm animals (Table 2).

Table 2. Livestock of farm animals in the Kurgan region, thousand heads (2016-2020)

\begin{tabular}{|c|c|c|c|c|c|}
\hline Name & 2016 & 2017 & 2018 & 2019 & 2020 \\
\hline \multicolumn{6}{|c|}{ Farms of all categories } \\
\hline Cattle & 117.5 & 117.0 & 122.0 & 120.8 & 120.5 \\
\hline Cows & 49.5 & 48.4 & 50.3 & 50.0 & 50.7 \\
\hline Pigs & 87.8 & 81.2 & 77.9 & 77.2 & 69.5 \\
\hline Sheep and goats & 125.5 & 118.2 & 114.4 & 111.8 & 108.7 \\
\hline Horses & 10.8 & 10.7 & 15.1 & 16.2 & 15.3 \\
\hline \multicolumn{6}{|c|}{ Households of the population } \\
\hline Cattle & 67.8 & 66.0 & 65.6 & 63.0 & 63.1 \\
\hline Cows & 29.1 & 28.4 & 28.3 & 27.5 & 27.3 \\
\hline Pigs & 44.1 & 33.7 & 34.4 & 32.4 & 27.8 \\
\hline Sheep and goats & 113.3 & 107.5 & 106.3 & 100.2 & 96.2 \\
\hline Horses & 6.9 & 6.8 & 10.7 & 11.6 & 10.7 \\
\hline
\end{tabular}


Table 2. Continued

\begin{tabular}{|l|c|c|c|c|c|}
\hline \multicolumn{7}{|c|}{ Peasant (farming) households and individual entrepreneurs } \\
\hline Cattle & 8.4 & 10.3 & 16.8 & 18.9 & 21.7 \\
\hline Cows & 4.1 & 4.8 & 7.8 & 8.8 & 10.1 \\
\hline Pigs & 15.7 & 18.8 & 15.4 & 15.9 & 16.7 \\
\hline Sheep and goats & 10.2 & 9.4 & 6.8 & 9.3 & 9.3 \\
\hline Horses & 1.0 & 1.1 & 1.7 & 2.0 & 2.4 \\
\hline
\end{tabular}

*according to the data of the Federal State Statistics Service

In households for the period from 2016 to 2020, there is a decrease in the number of livestock, by $7.0 \%$, and in farms of all categories and in peasant (farm) farms $(\mathrm{K}(\mathrm{F}) \mathrm{Kh})$, the number of cattle, including cows increased in organizations of all categories by $2.5 \%$, in individual entrepreneurship farms by -2.5 times. During the same period, in all forms of farming, the number of pigs, sheep and goats decreased, but there is a positive dynamics of increase in the number of horses for the period under review.

With regard to the volume of production of farm animals, a similar trend can be traced (Table 3).

Table 3. Production of basic livestock products by category of farms in the Kurgan region for 20162020

\begin{tabular}{|c|c|c|c|c|c|}
\hline & 2016 & 2017 & 2018 & 2019 & 2020 \\
\hline \multicolumn{6}{|c|}{ Farms of all categories } \\
\hline $\begin{array}{l}\text { Livestock and poultry } \\
\text { produced thousand tons }\end{array}$ & 67.1 & 68.5 & 70.6 & 68.4 & 68.5 \\
\hline Milk, thousand tons & 216.1 & 212.8 & 202.1 & 195.5 & 189.9 \\
\hline Eggs, mln. pcs. & 102.0 & 96.6 & 94.6 & 91.8 & 91.5 \\
\hline \multicolumn{6}{|c|}{ Households of the population } \\
\hline $\begin{array}{l}\text { Livestock and poultry } \\
\text { produced thousand tons }\end{array}$ & 42.6 & 41.7 & 41.8 & 41.3 & 40.1 \\
\hline Milk, thousand tons & 143.0 & 139.9 & 127.9 & 125.5 & 122.9 \\
\hline Eggs, mln. pes. & 84.3 & 80.6 & 78.7 & 78.1 & 77.5 \\
\hline \multicolumn{6}{|c|}{\begin{tabular}{|c|} 
Peasant (farming) households and individual entrepreneurs \\
\end{tabular}} \\
\hline $\begin{array}{l}\text { Livestock and poultry } \\
\text { produced thousand tons }\end{array}$ & 2.8 & 4.1 & 5.4 & 5.1 & 5.5 \\
\hline Milk, thousand tons & 7.8 & 7.8 & 11.1 & 12.8 & 12.9 \\
\hline Eggs, mln. pcs. & 4.6 & 3.1 & 3.1 & 1.5 & 1.4 \\
\hline
\end{tabular}

* according to the data of the Federal State Statistics Service

In 2020, in small forms of individual entrepreneurship, the production of livestock and poultry meat (in live weight) increased by 2.0 times, in farms of all categories - by $2.0 \%$. In the households of the population there was a decrease in this indicator - by $5.9 \%$. For the years under consideration, in these forms of management, there is a decrease in milk yield and egg collection, - by $14.0 \%$ and $8.1 \%$, respectively. In small forms of individual entrepreneurship, milk production increased by $65.3 \%$, but in this form of farming, egg production decreased by $70 \%$.

The volume of sales of agricultural products includes the sale of products by agricultural organizations through all channels: organizations that purchase for state and municipal needs, processing organizations, wholesale trade organizations, in markets, stock exchanges, auctions, through their own distribution network and public catering organizations, in the order wages, barter, and etc. (Figure 2). 


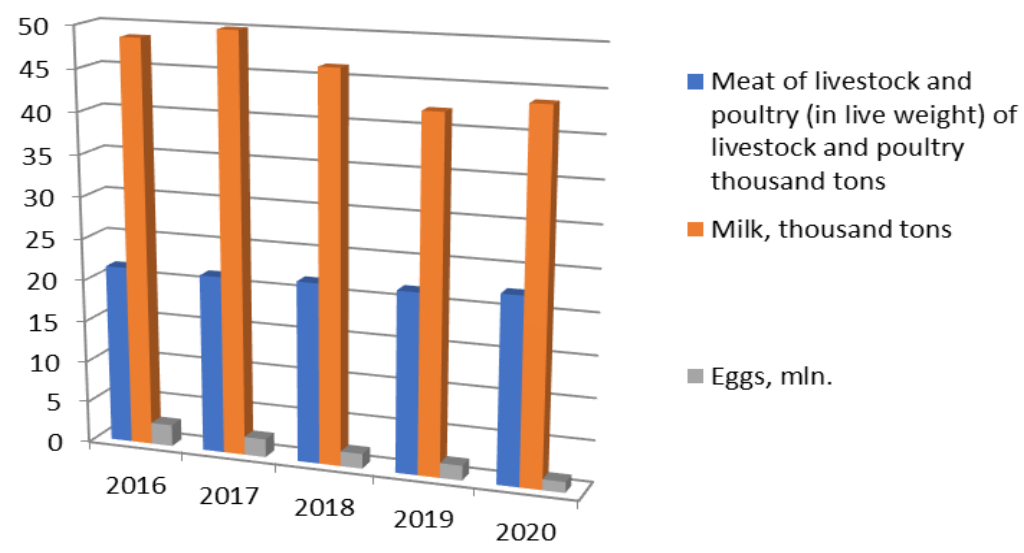

Fig. 2. Sales of livestock products by agricultural organizations

Based on the data in Figure 3, it can be seen that the sale of agricultural products of all organizations, there is a slight increase in the sale of cattle meat by $4.9 \%$ in 2020 compared to 2016 , as well as an increase in the sale of eggs by $37.5 \%$; during the period under review, the volume of milk sales decreased by $11 \%$ [7-8].

Analyzing the positive changes in the increase in the production of livestock products of agricultural organizations, it can be assumed that the livestock industry in the region has a future, if the government pays attention to this, allocating material assistance and other support measures for livestock farming [9-10].

\section{Conclusions}

There are positive changes in the development and activities of the agricultural sector of the Kurgan region in the livestock industry, but at the same time there are problems that hinder the development of this industry:

1. High cost of purchasing feed and low purchasing price of livestock products (milk and meat).

2. Low economic indicators were obtained in dairy cattle breeding, which is an obstacle to attracting investments.

3. High degree of depreciation of fixed assets.

4. Lack of financial resources for technical re-equipment of farms in the agricultural sector.

5. Low provision of highly qualified personnel [6].

In general, the high risk of innovative projects, unequal competition conditions in the domestic food market, the underdevelopment of the insurance and guarantee system in the implementation of projects, all these conditions, hinder the development in the agricultural sector of the Kurgan region, including in the livestock industry.

\section{References}

1. S. A. Zotov, Bulletin of the Saratov State Socio-Economic University, 2(46), 4750 (2013)

2. A. Bogoviz, S. Shkodinsky, E. Kondratieva, S. Lobova, A. Bazanova, Agro-industrial complex: Economics, Management, 8, 4-14 (2017) 
3. N.D. Gushchenskaya, D.V. Paliy, M.A. Sumarokova, A.U. Yesembekova, A.Yu. Anfalova, M.V. Pavlutskikh, International Transaction Journal of Engineering. Management. \& Applied Sciences \& Technologies, 11(14), 143-152 (2011)

4. T.I. Mazaeva, Bulletin of the University, 1, 59-63 (2012)

5. N.D. Gushchenskaya, D.V. Paliy, M.A. Sumarokova, M.V. Pavlutskikh, EcologicalSocio-Economic Systems: Models of Competition and Cooperation (ESES 2019), Advances in Social Science, Education and Humanities Research, 392, 357-360 (2020)

6. S.Yu. Kornekova, E.D. Abdulhamidov, Society. Wednesday. Development, 4(29), 3134 (2013) N. Yu. Novikova, Agro-food policy of Russia, 4(16), 19-21 (2013)

7. Nina Roznina, Maria Karpova, Alla Shulgina, Valentina Borovinskikh, Alevtina Volkova, Agricultural development of the Kurgan region in modern conditions, 10001 (2021)

8. Nina V. Roznina, Maria V. Karpova, Yevgenia S. Sokolova, Valentina A. Borovinskikh, Valentina M Flakin, The European Proceedings of Social and Behavioural Sciences EpSBS (2021)

9. L. R. Slepneva, I. V. Badmaeva, Bulletin of the Trans-Baikal State University, 12, 154159 (2014)

10. N. V. Yakovenko, Almanac of modern Science and education, 3, 205-207 (2009) 